\title{
Saint Lucia
}

National Cancer Institute

\section{Source}

National Cancer Institute. Saint Lucia. NCI Thesaurus. Code C17113.

An island between the Caribbean Sea and the North Atlantic Ocean, south of Martinique and north of Saint Vincent and the Grenadines. 